\title{
GLOBALIZATION IN TOURISM
}

\author{
Prof. Agnieszka Brelik ${ }^{1}$ \\ ${ }^{1}$ West Pomeranian University of Technology in Szczecin, Faculty of Economics Department \\ of European and Regional Studies
}

\begin{abstract}
The globalization process, which causes the interdependence of world economies, is identified mainly in the economic and social area. Analysing statistical data on tourism, it can be stated that globalization positively influences the shaping and development of the tourism economy. The process itself, taking into account the capital links of the tourism services markets, is sensitive to crisis situations. It was important to present the tourist traffic in the globalization process. The article is of review and conceptual nature. The purpose of the article was to identify the phenomenon of globalization in tourism. The research was conducted using a review of national and foreign literature on the subject as well as descriptive and comparative analysis.
\end{abstract}

Key words: globalization, tourism economy, tourism, tourist traffic.

JEL code: Q18

\section{Introduction}

As an important branch of many contemporary national economies, tourism is considered to be a significant tool of economic development. It functions as a factor stimulating both local and regional socioeconomic development on a micro- and macroeconomic scale. The development of entrepreneurship through the amount of taxes paid stimulates the development of individual regions and the entire country. Tax revenues make it possible to make the necessary investments in tourism. This, in turn, increases the attractiveness of the given country. Due to the demand for tourist services, which grows each year, the development of this sector globally impacts the level of entrepreneurship, investments, and innovations. A change in the direction of development and the economy-stimulating function contributes to the emergence of new tourist destinations, attractive for tourist traffic. There is no doubt that globalisation is most closely connected with the economic sphere. It also clearly involves the civilisation, cultural, and political aspects. The process applies in particular to the issues of safety, culture, trade, and tourism. The globalisation of the tourist market has actually been progressing since the early 1950s, along with the development of transnational corporations which have branches in most countries and satisfy a considerable proportion of the global tourist demand (Kachniewska M., 2007). It is therefore important to present the tourist traffic in the process of globalisation.

\section{Material and methods}

The data from 2006-2016 (statistic) and WTO report were used to assess the impact of globalization on tourism in North Amerika, Asia Pacific, Middle East and Europe. The article is a review of a conceptual nature. The aim of the article is to identify the phenomenon of globalisation in tourist traffic. Research was carried out using a review of domestic and foreign source literature, as well as a descriptive and comparative analysis.

\section{Globalisation - term overview}

The history of the globalisation process is just as rich as the history of international relations. First mentions of the issue appeared towards the end of the 17 th century (Cheater A. P., 1995: 124). They gained significance in the 1980 s and 1990s. Since that time, the phenomenon has been the subject of numerous studies. Research on the topic is of great interest to various researchers, economists in particular, but also political scientists and sociologists and representatives of other fields. Globalisation theoreticians include H. M. McLuhan, who promoted 
the global village theory, Q. Wright, author of the concept of common culture, and W. Coplin promoting the idea of universal culture.

It is difficult to pinpoint a single definition of globalisation, as over the years, the term has been used to describe numerous processes. Source literature usually cites Marshall McLuhan of McGill University, who - recognising a huge influence of new communication technologies on social and cultural life - called the world a "global village" for the first time in 1964 (Seidel F. P.). The notion of globalisation is closely connected with the global economy, in which production factors, as well as products and services, circulate around the world (Thurow L. C.).

Globalisation leads to the formation of trade blocks, global companies, and global economy. The world thus becomes a single system, and the global market accessible to all. Economic globalisation offers many possibilities to countries around the world. Thanks to these possibilities, many countries have advanced from global margins to highly developed countries and may serve as a good example to other countries that are just starting to conquer the market.

Globalisation leads to the formation of trade blocks, global companies, and global economy. The world thus becomes a single system, and the global market accessible to all (Deszczynski P., 2009). Economic globalisation offers many possibilities to countries around the world. Thanks to these possibilities, many countries have advanced from global margins to highly developed countries and may serve as a good example to other countries that are just starting to conquer the market (Veselica V., 2007).

According to A. McGrew (McGrew A., 1992), globalisation consists of a multitude of interconnections and a mutuality of influences between countries and societies making up the current global system. Globalisation is therefore marked by two dimensions: scope and intensity. It is characterised by the expansion of an enterprise beyond the borders of the country of its headquarters, international capital flows, and the broadening of the scope of the business activity conducted and services offered (Rosinska-Bukowska M., 2009).

Globalisation is therefore a dynamic process, which is why its degree and course may change in various fields, may concern both commodity markets and service markets, manufacturing, industry, technology, and knowledge, as well as consumption and mass culture patterns.

Wahab S. and Cooper C. (2001: 4) give a description of globalisation as it is understood in current times, one that coincides with many popular interpretations: Therefore, globalisation is an all-embracing term that denotes a world which, due to many politico-economic, technological and informational advancements and developments is on its way to becoming borderless and an interdependent whole. Any occurrence anywhere in the world would, in one way or the other, exert an impact somewhere else. National differences are gradually fading and being submerged in a homogeneous mass or a single socioeconomic order.

The issue of the paradoxical nature of the contemporary globalisation processes is raised very often. For globalisation triggers phenomena and processes which - as it seems - are mutually opposed or at least head in different directions (Masloch P., 2005). Globalisation is therefore a set of processes of multidimensional nature, it integrates entities on an international scale, both socially and economically. It is influenced by numerous factors; in the economic sphere, it is closely connected with the scientific and technical revolution. It is considered as an inevitable fate of the world (Bauman Z., 2008). According to Robertson, the theory of globalisation is an analytical pattern, which may serve as basis for reflection on describing phenomena of supranational significance. Globalisation is a process of economic, social, cultural, and political activity crossing 
national boundaries (Robertson R., 1992). Globalisation is analysed in many aspects: an economic and geographical one, the aspect of universal values, and the aspects of the global cultural industry and political industry, poverty, and intercultural conflicts. The globalisation of the local environment results in the globalisation of competition and the implementation of global strategies. Since the mid-1980s, the dynamics of global trade have considerably exceeded the increase of the gross world product. These dynamics are higher with reference to trade within geographical regions than between them. Globalisation goes beyond a typically economic phenomenon, it is rather a megatrend which leads to the internationalisation of social, cultural, and political relations. It is a clear, dynamic, and heterogeneous process, which will change the world into a global village (Ostrowska B., 2011).

The process of the globalisation of economies was, however, stopped by a number of dramatic political and economic events in the period between World War I and the end of World War II, and the next dozen or so years of economic recovery of individual countries. Currently, we are therefore dealing with another, second stage of globalisation, the stage of dynamic development thanks to unprecedented scientific and technical progress and the development of economies and the international market (Zorska A., 1998). Globalisation processes impact the shape of tourist traffic in tourist regions.

\section{Results and discussion}

The term globalisation is a means of describing a process: it does not offer any explanations. World-system theory analyses and offers an explanation of the historical and social development of a process and a system - a system that may itself be described as an example of globalisation. Tourism is regarded as part of the process of globalisation.

The following factors have a considerable influence on globalisation in tourism:

- unlimited access to information,

- development and constant modernisation of means of transport,

- free markets and the related foreign trade, expansion of hotel chains into international markets,

- significant demand for tourist services,

- international competition.

On a global scale, tourism is treated as a priority sector on account of the economic benefits. In 2016, tourism generated $12 \%$ of the gross world product. In the economy, tourism mostly serves the macroeconomic functions and may stimulate socioeconomic development of tourist reception areas, and consequently of the country's economy by: - creating added value, thanks to which it contributes to the growth of the gross domestic product, - increasing foreign exchange revenues obtained from handling tourist traffic, - stimulating the development of entrepreneurship and infrastructure, - creating new jobs and increasing the income of the population of tourist regions, - increasing the income of companies offering services to tourists and favouring entrepreneurship and innovation, - shaping budget revenues of the local authorities. The GDP of the given country largely depends on the level of income from the sales of tourist services. This results from the fact that business entities participating in the handling of tourist traffic form a service chain made up of the following links: hotels, restaurants, travel agencies, transport companies.

The tourist sector is improving its results in spite of the growing problems related to safety in many regions of the world. The geographical distribution of tourist traffic and receipts from tourism 
is not homogeneous. Despite the internationalisation of tourist demand, on each continent, internal markets and the markets of the neighbouring countries remain the most important regions for international tourism for the given continent.

The direct economic contribution of travel and tourism amounted to approximately 2.31 trillion U.S. dollars in 2016. The direct travel \& tourism contribution includes the commodities accommodation, transportation, entertainment and attractions of these industries: accommodation services, food and beverage services, retail trade, transportation services and cultural, sports and recreational services. The figures for total impact also include indirect and induced contributions (Figure 1).

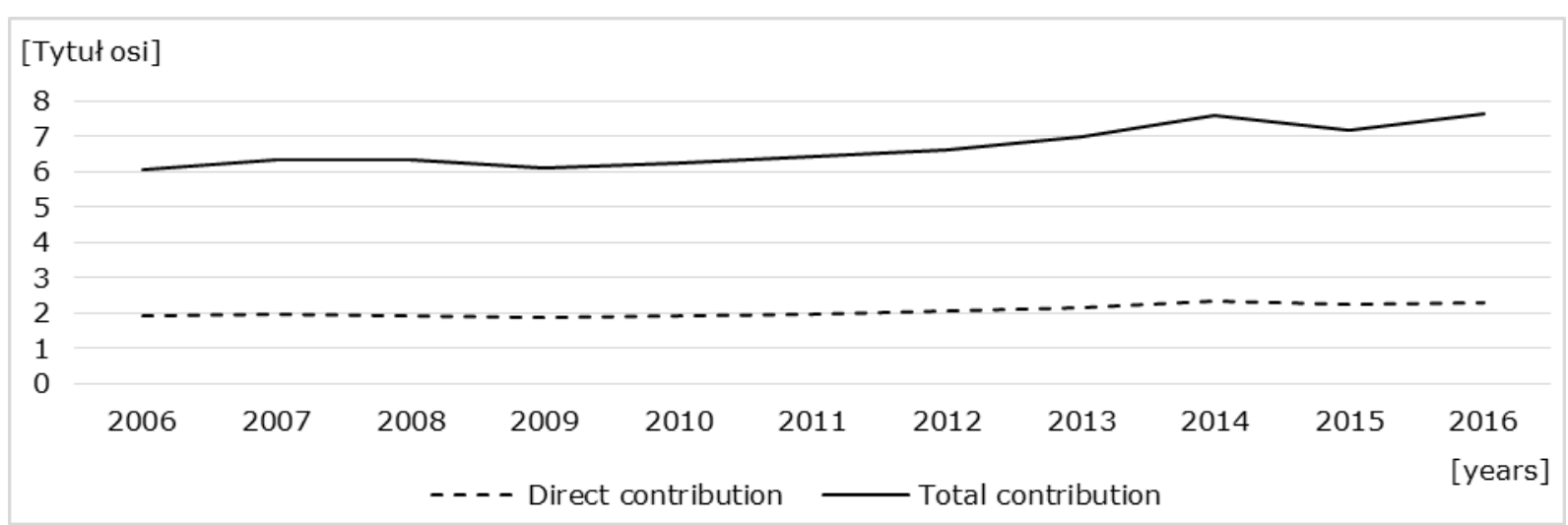

Source: author's elaboration based on https://www.statista.com (date of access 01/12/2017)

Fig. 1. The direct and total economic impact of travel and tourism on the global economy from 2006-2016

The GDP of the given country largely depends on the level of income from the sales of tourist services. This results from the fact that business entities participating in the handling of tourist traffic form a service chain made up of the following links: hotels, restaurants, travel agencies, transport companies. The entities contributing to the part of the GDP obtained from tourism to the greatest extent are usually hotels and transport companies. Additionally, the intensity of tourist traffic depends on the political and economic situation both of the given country and across the world. This trend was clearly visible after the 9/11 attacks or during the 2007 economic crisis, when a significant decrease in the global level of tourist travel could be observed. Travel and tourism's total contribution to global GDP reached 7.58 trillion U.S. dollars in $2014-3.85$ trillion of this figure came from leisure spending.

The number of international inbound tourists across the world increases each year within a decade. It is expected that by 2020, the number of inbound tourists will have reached about 1.36 billion and may exceed 1.8 billion by 2030. In 2016, North America was visited by more than 130.5 million international tourists, while in the Middle East, the number of tourists oscillated in the region of 53.6 million. The increase in inbound tourist traffic is largely related to the growing exchange between the developed regions of the world. The process of globalisation in tourism clearly shows that traditional tourist areas are losing its share in the market in favour of the more and more rapidly developing competitors (WTO, 2017).

In recent years, the travel and tourism industry has contributed around seven trillion U.S. dollars to the global economy annually, nearing eight trillion in 2016. A highly profitable and valuable industry to the global economy, travel and tourism makes a direct economic impact of more than two trillion U.S. dollars each year. North America makes the largest contribution in this area, closely followed by the European Union and North East Asia. Due to their less developed 
tourism industries, regions such as North and Sub Saharan Africa make a much smaller impact. However, according to the World Travel and Tourism Council (WTTC), some of the fastestemerging tourism destinations can be found in Africa, including Namibia, Zambia and Angola. This is perhaps due to the realization of the benefits travel and tourism can provide for a country's economy, or maybe because of the growing popularity of less-travelled destinations among global tourists. This is not to say travellers are not still visiting well-established tourism destinations in their millions - the number of overseas visitors to the United States, for example, is still increasing each year and is expected to exceed 40 million by 2018. Travel and tourism's total contribution to global GDP reached 7.58 trillion U.S. dollars in 2014 - 3.85 trillion of this figure came from leisure spending. In that year, there were 973.8 million international tourist arrivals worldwide, over half of these visiting Europe. This number had increased by around 250 million since 2005 and was forecasted to almost double to 1.81 billion by 2030 (WTTC, 2017).

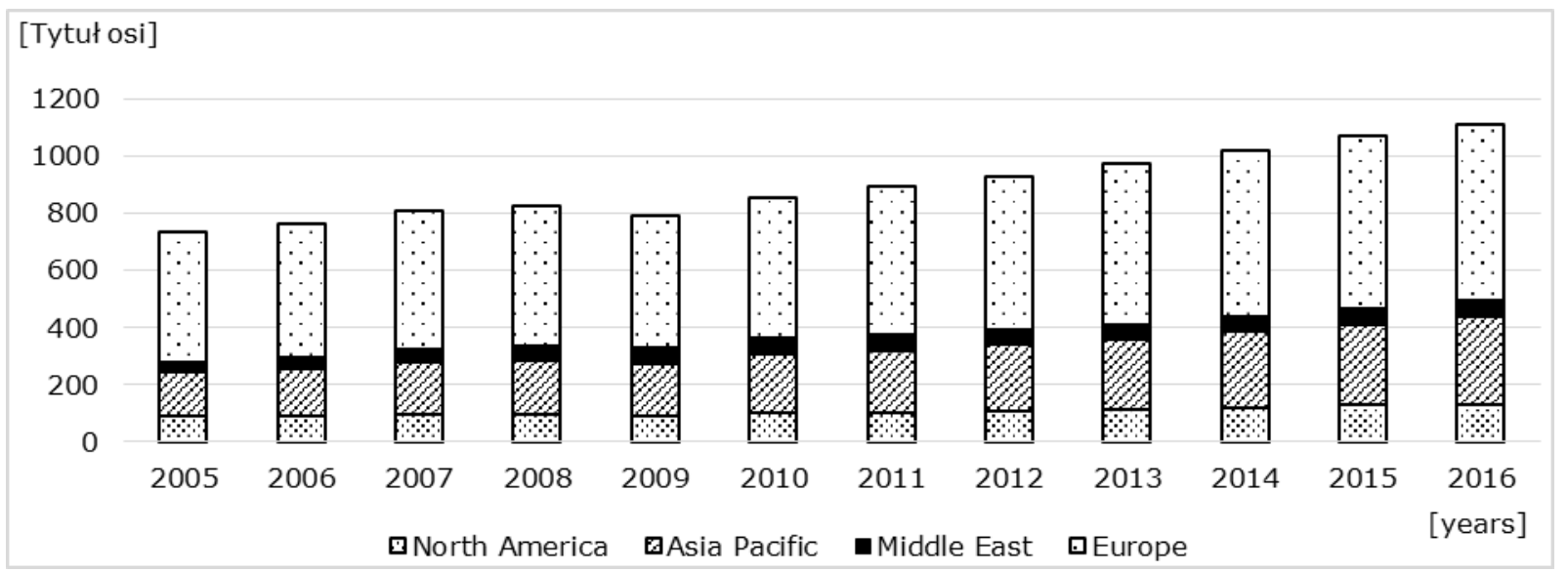

Source: author's elaboration based on https://www.statista.com (date of access 01/12/2017)

Fig. 2. The number of international tourist arrivals worldwide in the period 2005-2016 by regions

The economic expression of the significance of tourism in the contemporary world are the receipts from international tourism and their dynamic increase both on a global scale and in the individual tourist regions. Tourism, including international tourism, contributes to the economic development above all thanks to the fact that it triggers the so-called multiplier effect, described by J. M. Keynes. An inherent characteristic of the tourist sector is the transfer of funds from the tourists' place of residence to their destinations. Arriving at tourist reception areas, tourists put certain funds into circulation, which can then be accumulated or expended further. Funds coming from tourists are exchanged for goods and services and then, redistributed, circulate in the economy, creating a financial effect at all the stages of financial turnover. Along with the development of large companies, price competition grows, which puts small and medium-sized enterprises in an unfavourable situation. Globalisation processes lead to global standardisation of the quality and comfort of tourist services.

The index was part of "The Travel \& Tourism Competitiveness Report 2015: Growth through Shocks." The report assessed worldwide economies on their travel and tourism development efforts and the impact of this on job creation.

\section{Applications, proposals, recommendations}

In the new system, the size and level of the global development of tourism, investment policy, and infrastructure development and planning is dictated directly by the development of international tourist traffic. Tourist corporations play an important role in promoting tourist 
destinations and encourage their development. Striving to improve the offering, they generate the added value of tourist demand. This creates a certain kind of a value chain which functions as a single system of interconnected content, aimed at achieving added value in tourism. Because the excess supply in the global tourist market causes increased requirements and expectations, only large corporations are able to provide comprehensive and diverse services for various segments of tourist demand. Hence, an important factor in shaping the contemporary tourist offering is the individualisation of travelling motives and styles, connected with the tourists' increased requirements and expectations as to the quality of tourist services. Global trends in tourism reflect the tourists' changing preferences and needs. An increase in the frequency of international trips during the year is clearly visible, and the growing number of flights creates favourable conditions for this phenomenon.

As a contemporary trend, globalisation has a deep impact on the general development of the global economy. All the economic trends influence the development of domestic or international tourism. In its essence, tourism is an international movement which contributes to the understanding of customs, religions, and social systems. It constitutes the strongest and the most flexible economic power in the global economy. At the same time, it is a significant export product with large employment opportunities.

Tourism is a contemporary phenomenon of globalisation, which appeared and developed at a certain stage of development of human society. Its influence combines economics, ecology, social factors, religious relations, cultures, and other scientific categories in the field of human activity (Smeral E., 1996: 395). We may not forget that the main effects resulting from the impact of globalisation processes on tourism are first of all a sharp rise in potential tourist demand for various destinations (and it needs to be pointed out that consumers who want new experience are not only attracted to destinations nearby, but the whole world becomes a potential destination). Secondly competition among tourist destinations has become extremely strong, and more destinations compete in the market basing their competitiveness on the requirements of the potential customers. Then small and medium-sized enterprises must fight for survival on the tourist market which is being conquered by large globalised corporations. Thirdly emphasis on introduction of innovation, specialisation and higher quality of products and services; increased need for extra capital to finance the necessary investments for future goals and achievements in order to stay competitive on the market. And finally fourth problems of developed tourist destinations arising from relationships with suppliers who are often not heterogeneous and do not apply quality standards.

\section{Bibliography \\ Books}

1. Bauman, Z. (2000). Globalizacja i co z tego dla ludzi wynika (Globalization and what's for it for people), Warszawa, p. 5

2. McGrew, A. (1992). Conceptualizing Global Politics, [w:] Global Politics, pod red. A. McGrew, Polity Press. Cambridge, p. 28.

3. Robertson R. (1992). Globalization. Sage, Newbury Park, London, New Delhi, p. 24.

4. Seidel, F.P. (2001). The Practice of Public Relations, Prentice Hall, New Jersey, p. 24.

5. Zorska, A. (1998). Ku globalizacji. Przemiany $w$ korporacjach transnarodowych $i$ w gospodarce swiatowej (Towards globalization. Transformation in Transnational Corporations and In The Global Economy), Wydaw. Naukowe PWN, Warszawa, p. 15.

6. Veselica, V. (2007). Globalization and new economy. 


\section{Articles}

7. Cheater, A.P. (1995). Globalisation and the new technologies of knowing: Anthropological calculus or chaos? In M. Strathern (ed.) Shifting Contexts: Transformations in Anthropological Knowledge. London: Routledge. p. Deszczynski, Konceptualizacja pojecia globalizacji (Conceptualisation of Globalisation Definitione) Zeszyty Naukowe Wyzszej Szkoły Bankowej w Poznaniu Nr 23/2009, p. 9.

8. Kachniewska, M. (2007). Franchising jako narzedzie budowy lancucha wartosci przedsiebiorstw hotelarskich na europejskim rynku turystycznym (Franchising as a Tool for Building the Value Chain of Hotel Enterprises on the European Tourism Market), Wspolna Europa. Tworzenie wartosci przedsiebiorstwa na rynku Unii Europejskiej, Szkola Glowna Handlowa w Warszawie, Warszawa, p. 103.

9. Masloch, p. (2005). Globalizacja i jej wplyw na rozwoj wspolczesnej cywilizacji (Globaisation and it's influence on development of contemporary civilization). Przedsiebiorczosc a wspolczesne wyzwania cywilizacyjne. Przedsiebiorczosc - edukacja, nr 1, Krakow (file:///C:/Users/user/Downloads/710-2155-1PB2.pdf, data dostępu: 06.12.2017)

10. Wahab, S., Cooper, C. (2001). Tourism, globalisation and the competitive advantage of nations. In S. Wahab and C. Cooper (eds) Tourism in the Age of Globalisation. London: Routledge.

11. Rosinska-Bukowska, M. (2009). Rola korporacji transnarodowych w procesach globalizacji. Kreowanie globalnej przestrzeni biznesowej, maszynopis.

12. Thurow, L.C. (1999). Przyszłosc kapitalizmu (The future of capitalism), Wyd. Dolnoslaskie, Wroclaw, s. 157 $-220$.

13. Smeral, E. (1996). Globalization and changes in the competitiveness of tourism destinations, 46th Congress Globalisation and Tourism. Rotura: Publication of the International Association of Scientific Experts in Tourism.

\section{Internet sources}

14. Miedzynarodowy ruch turystyczny - szacunki UNWTO (International tourist traffic - UNWTO estimates).

15. Ministerstwo Sportu i Turystyki https://www.msit.gov.pl/pl/aktualnosci/6068,Miedzynarodowy-ruchturystyczny-szacunki-UNWTO.html (dostęp: 20.02.2018).

16. Ostrowska B. (2018). Globalizacja swiatowej gospodarki a trendy we wspolczesnej turystyce (Globalization of the global economy and trends in modern tourism) https://repozytorium.ka.edu.pl/bitstream/handle/11315/1748/Ostrowska_

Barbara_Globalizacja_swiatowej_gospodarki_2011.pdf?sequence=1 (date of access: 20.02.2018).

17. World Travel and Tourism Counil TRAVEL \& TOURISM GLOBAL ECONOMIC IMPACT \& ISSUES 2017 (date of access: 20.02.2018)

18. www.statista.com (date of access: 01/12/2017)

19. The Travel \& Tourism Competitiveness Report 2015: Growth through Shocks. http://www3.weforum.org/docs/TT15/WEF_Global_Travel\&Tourism_Report_2015.pdf (date of access: $01 / 12 / 2017)$ 